ISSN 1392-3196 / e-ISSN 2335-8947

Zemdirbyste-Agriculture, vol. 105, No. 4 (2018), p. 369-376

DOI $10.13080 /$ z-a.2018.105.047

\title{
Bacillus isolates as potential biocontrol agents of Fusarium clove rot of garlic
}

\author{
Dragana BJELIĆ ${ }^{1}$, Maja IGNJATOV ${ }^{1}$, Jelena MARINKOVIĆ ${ }^{1}$, Dragana MILOŠEVIĆ ${ }^{1}$, \\ Zorica NIKOLIĆ ${ }^{1}$, Jelica GVOZDANOVIĆ-VARGA ${ }^{1}$, Maja KARAMAN ${ }^{2}$ \\ ${ }^{1}$ Institute of Field and Vegetable Crops \\ Maksima Gorkog 30, 21000 Novi Sad, Serbia \\ E-mail: dragana.bjelic@nsseme.com \\ ${ }^{2}$ University of Novi Sad \\ Trg Dositeja Obradovića 2, 21000 Novi Sad, Serbia
}

\begin{abstract}
Clove rot caused by Fusarium spp. is a very important disease of common garlic (Allium sativum L.) occuring in many areas of the world. However, there is a lack of data about biocontrol of these pathogens. Bacillus species are attractive for research due to their potential use in the biological control of fungal diseases. The aim of this study was to select effective biocontrol agents from a series of indigenous Bacillus spp. isolated from soil. Bacterial isolates positive for hydrolytic enzymes production were screened for antifungal activity against Fusarium spp. isolated from infected garlic cloves. Polymerase chain reaction (PCR) analyses were used for molecular identification of bacterial (16S rDNA gene) and fungal (EF-1 $\alpha$ gene) isolates, and detection of biosynthetic genes for antimicrobial lipopeptides (surfactin, iturin, bacillomycin D and fengycin) in Bacillus spp.

The obtained results confirmed the presence of Fusarium tricinctum, F. oxysporum f. sp. cepae, F. proliferatum, $F$. acuminatum and $F$. verticillioides as the causal agents of garlic clove rot. Four bacterial isolates identified as Bacillus subtilis exhibited the highest antagonistic effect during in vitro testing of antifungal activity (up to $71 \%$ reduction in fungal growth), and caused a significant suppression of garlic clove infection (up to $58 \%$ reduction in rot symptoms) in situ. Analysis of the antifungal compounds involved in the antagonistic activity of the examined isolates revealed their ability to produce the antibiotic lipopeptide surfactin. The most effective isolates of $B$. subtilis could be used as potential biocontrol agents of garlic clove rot.
\end{abstract}

Key words: Allium sativum, antifungal activity, Bacillus subtilis, lipopeptides.

\section{Introduction}

Common garlic (Allium sativum L.) is one of the major vegetable crops grown on average on an area of 1.5 million ha, with an annual production of 24.9 million tons (FAO, 2014, http://www.fao.org/faostat/en/\#data/ QC). Beside for culinary purposes, garlic is also widely used as a prophylactic as well as therapeutic medicinal plant. Different compounds in garlic are thought to have antimicrobial, anticancer, antidiabetic, antiinflammatory, antioxidant and cardioprotective activities (Martins et al., 2016). The unique flavour and health-promoting functions are usually attributed to organosulfur compounds in garlic, such as allicin, ajoene and diallyl sulfides (Rahman, 2007). Regardless, garlic is prone to several diseases, which indicates the severity of the causing pathogens.

Rot disease caused by Fusarium spp. is one of the most serious threats to garlic production worldwide. Fungi are transmitted by soil and can persevere for a long time in the soil and plant residues (Koleva, 2004). The disease may occur both in the field and in the storage, with intense development when environmental conditions are suitable and plants are susceptible to infection (Palmero et al., 2013). Disease is favoured by higher $\left(20-30^{\circ} \mathrm{C}\right)$ temperatures and high humidity. Garlic bulbs are quite perishable because of their high moisture content (Schwartz, Mohan, 2008). Plants may show decreased germination and necrosis of leaves, while infected bulbs become undersized, softened, brown and watery, with white, light purple or red mycelium on the cloves (OSU, 2008). Additionally, Fusarium spp. lead to a serious reduction in yield and represent an important safety interest due to their ability to produce numerous mycotoxins such as fumonisin, moniliformin, beauvericin, fusaric acid and fusaroproliferin (Stanković et al., 2007).

Different strategies have been used for the suppression of garlic rot, including fungicide treatments and preventive detection of infection before seeding, but none of them are enough to control the disease (Dugan et al., 2007). The demand for alternative control strategies, particularly the use of biopesticides, has been increasing steadily due to environmental awareness 
and potential health hazards from chemical pesticides (Ansari et al., 2012). Bacillus spp. are attractive for research due to their possible utilization in the biological control of fungal diseases (Mardanova et al., 2017). They offer several preferences over other microorganisms because of their ability to form endospores and tolerate adverse environmental conditions (Islam et al., 2012). Furthermore, their long term viability and rapid growth in a liquid medium simplify the production of commercial preparations (Wu et al., 2015).

Antimicrobial activities of Bacillus spp. were usually associated to the synthesis of secondary metabolites with antibiotic properties such as cyclic lipopeptides, namely surfactin, iturin and fengycin (Cawoy et al., 2015). These lipopeptides can also influence the root colonization and interaction of Bacillus spp. with plants by stimulating host defence mechanisms (Ongena, Jacques, 2008). Other biocontrol mechanisms of Bacillus spp. involve the excretion of cell wall hydrolases, competition for nutrients and/or elicitation of induced systemic resistence (Lugtenberg et al., 2013). Moreover, Bacillus spp. had the ability to promote plant growth through asymbiotic nitrogen fixation, phosphate solubilization, production of phytohormones, siderophores and enzymes (Borriss, 2011).

It has been found that Bacillus spp. exert beneficial effects on plant growth and disease suppression of various crops (Mnif, Ghribi, 2015). However, the lack of data about biocontrol of garlic pathogens is evident in literature. Considering the increasing occurrence of Fusarium rot on garlic in Serbia (Stanković et al., 2007; Lević et al., 2009; Ignjatov et al., 2017 a; b), it is necessary to investigate the possibilities of using Bacillus spp. as potential biocontrol agents of the disease. The aim of this study was to isolate Bacillus spp. from soil and to evaluate their antifungal activities toward Fusarium spp. isolated from infected garlic cloves.

\section{Materials and methods}

Isolation and molecular identification of Bacillus and Fusarium species were performed during 2015-2016, while polymerase chain reaction (PCR) detection of antimicrobial lipopeptides, hydrolytic and antifungal activity assays were conducted during 20162017. All experiments were performed in the Laboratory for Microbiology and Laboratory for Seed Testing of Institute of Field and Vegetable Crops, Novi Sad, Serbia. Isolation of Bacillus spp. Bacillus spp. were isolated from soil samples collected in several locations in Serbia as described by Bjelić et al. (2017). Soil samples included the rhizosphere of plants, agricultural and non-agricultural soils, and differed in their physical and chemical properties, cropping and tillage history. In short, soil samples were taken up to a depth of $20 \mathrm{~cm}$, sieved and stored at $4{ }^{\circ} \mathrm{C}$ until processed. Soil suspensions ( $1 \mathrm{~g}$ of soil in $9 \mathrm{ml}$ of $0.85 \% \mathrm{NaCl}$ ) were serially diluted $\left(10^{-3}-10^{-6}\right)$ and $0.1 \mathrm{ml}$ aliquots were spread on plates containing nutrient agar. Followed by $24 \mathrm{~h}$ incubation at $30^{\circ} \mathrm{C}$ and several recultivations of single colonies on nutrient agar, the bacterial isolates were characterized according to morphological and biochemical properties (Cappuccino, Welsh, 2016).

Isolation of Fusarium spp. Fusarium spp. were isolated from rot symptomatic garlic bulbs collected from several storages in Vojvodina Province, northern Serbia. Cloves were separated from the bulbs, and surface disinfested in $1 \% \mathrm{NaOCl}$ for 2 to $3 \mathrm{~min}$, rinsed with sterilized distilled water three times, and then dried on sterile filter paper under aseptic conditions. Pieces of infected clove tissues ( 3 to $4 \mathrm{~mm}$ ) were cut and plated onto a potato dextrose agar (PDA) amended with $300 \mathrm{mg}$ $\mathrm{l}^{-1}$ streptomycin sulfate $(\mathrm{w} / \mathrm{v})$. Plates were incubated at $25^{\circ} \mathrm{C}$ in the dark. Seven days later, Fusarium colonies were recognized morphologically and isolates were subcultured in PDA using the single spore technique.

Pathogenicity. Confirmation of pathogenicity was conducted for twenty Fusarium spp. isolates. Cloves of the common garlic (Allium sativum L.) cultivar 'Bosut' (developed at the Institute of Field and Vegetable Crops, Novi Sad, Serbia) were surface sterilized in $0.5 \% \mathrm{NaOCl}$ for $1 \mathrm{~min}$, rinsed in four changes of sterile water and wounded to a depth of $4 \mathrm{~mm}$ using a $1-\mathrm{mm}$ diameter probe (Palmero et al., 2012). Each of the 7 dayold fungal isolates was inoculated into five wounded cloves and incubated in a growth chamber at $25^{\circ} \mathrm{C}$ for 3 weeks. Six randomly selected isolates of Fusarium spp. were re-isolated from artificially inoculated garlic cloves fulfilling Koch's postulates, and incubated at $25^{\circ} \mathrm{C}$ for 7 days before use. Morphology of macroconidia, microconidia and chlamydospore was assessed from cultures grown on PDA and carnation leaf agar (CLA) (Leslie, Summerell, 2006).

In vitro hydrolytic activity assay. Screening for lytic enzyme production in indigenous Bacillus spp. isolates included determination of lipase, phospholipase, pectinase and cellulase activity (Djuric et al., 2011). Lipase production was confirmed on a medium with the addition of polysorbate Tween 80 (Sigma-Aldrich, USA), after 7 days of incubation at $28^{\circ} \mathrm{C}$, by the formation of dark and opaque zone around the colonies. Production of phospholipase was assayed on a medium supplemented with egg yolk, after $48 \mathrm{~h}$ of incubation at $28^{\circ} \mathrm{C}$, by the appearance of an opaque zone around the colonies. Pectinase production was determined on a pectin agar after $48 \mathrm{~h}$ of incubation at $28^{\circ} \mathrm{C}$ and pouring with $2 \mathrm{M} \mathrm{HCl}$, by the appearance of a clear zone around the colonies. Production of cellulase was assayed on the carboxyl methyl cellulose (CMC) agar, after 7 days of incubation at $28^{\circ} \mathrm{C}$ and pouring $0.1 \%$ Congo Red solution into $1 \mathrm{M} \mathrm{NaCl}$, by the appearance of a clear zone around the colonies.

Molecular species identification. Bacillus spp. isolates for DNA extraction were grown on nutrient agar plates for $24 \mathrm{~h}$, while DNA from Fusarium spp. isolates was extracted from the 7-day-old mycelium (100 mg wet weight) grown on PDA plates. DNA from bacterial and fungal isolates was extracted using a DNeasy Mini Kit (QIAGEN Inc., Germany). Universal primers fD1 (27F) (AGAGTTTGATCMTGGCTCAG) and rP3 (1492R) (TACGGYTACCTTGTTACGACTT) were used for the amplification of $16 \mathrm{~S}$ rDNA gene fragments of Bacillus isolates (Weisburg et al., 1991). The translation elongation factor-1 alpha $(\mathrm{EF}-1 \alpha)$ gene region of Fusarium isolates was amplified with the primer pair EF1 (ATGGGTAAGGAGGACAAGAC) and EF2 (GGAAGTACCAGTGATCATGTT) (Geiser et al., 2004). Amplifications were performed in a Mastercycler PCR device (Eppendorf, Germany). Amplicons were electrophoresed in a $1.5 \%$ agarose gel containing ethidium bromide $\left(0.5 \mu \mathrm{g} \mathrm{ml}^{-1}\right)$. All sequences were deposited in the GenBank and compared with the previously reported sequences available in the NCBI (National Center for Biotechnology Information). 
In vitro antifungal activity assay. The ability of Bacillus spp. isolates to inhibit the growth of six Fusarium spp. isolates was examined using a dual plate assay (Zhao et al., 2010). The 7-day-old mycelial plugs on PDA (6 mm in diameter) of each fungus were aseptically transferred on the same medium, previously streaked with a broth culture of the tested bacteria. After 7 days of incubation at $25^{\circ} \mathrm{C}$, the fungal growth in the control (C) and dual cultures (R1) were measured and the percent of growth inhibition (PGI) was calculated according to the formula: PGI $(\%)=[(\mathrm{C}-\mathrm{R} 1) / \mathrm{C}] \times 100$. Antifungal activity assay was repeated twice, with three replications for each fungal and bacterial isolate.
Polymerase chain reaction (PCR) detection of antimicrobial lipopeptides. Detection of biosynthetic genes for antimicrobial lipopeptides: surfactin ( $s f p)$, iturin (itu), bacillomycin D (bamC) and fengycin (fenD) in Bacillus spp. isolates was carried out using four sets of primers. Primers and corresponding genes for PCR detection of antimicrobial lipopeptides are listed in Table 1. DNA from Bacillus spp. was isolated as described earlier. The PCR for the detection of the antimicrobial lipopeptides was programmed as described by Dimkić et al. (2013). Following PCR, the amplified products were electrophoresed as described earlier.

Table 1. Primers and corresponding genes for polymerase chain reaction (PCR) detection of antimicrobial lipopeptides

\begin{tabular}{|c|c|c|c|c|}
\hline Lipopeptide & Gene & Primer & Sequence & $\begin{array}{l}\text { Product size } \\
\text { bp }\end{array}$ \\
\hline Surfactin & $s f p$ & $\begin{array}{l}\text { P17 } \\
\text { P18 }\end{array}$ & $\begin{array}{l}\text { ATGAAGATTTACGGAATTTA } \\
\text { TTATAAAAGCTCTTCGTACG }\end{array}$ & $\sim 675$ \\
\hline Iturin & itu & $\begin{array}{l}\text { ITUP1F } \\
\text { ITUP2R }\end{array}$ & $\begin{array}{l}\text { AGCTTAGGGAACAATTGTCATCGGGGCTTC } \\
\text { TCAGATAGGCCGCCATATCGGAATGATTCG }\end{array}$ & $\sim 2000$ \\
\hline Bacillomycin D & bamC & $\begin{array}{l}\text { BACC1F } \\
\text { BACC1R }\end{array}$ & $\begin{array}{l}\text { GAAGGACACGGCAGAGAGTC } \\
\text { CGCTGATGACTGTTCATGCT }\end{array}$ & $\sim 875$ \\
\hline Fengycin & fenD & $\begin{array}{l}\text { FEND1F } \\
\text { FEND1R }\end{array}$ & $\begin{array}{l}\text { TTTGGCAGCAGGAGAAGTT } \\
\text { GCTGTCCGTTCTGCTTTTTC }\end{array}$ & $\sim 964$ \\
\hline
\end{tabular}

In situ antifungal activity assay. Antifungal activity of Bacillus spp. on garlic cloves infected with Fusarium spp. isolates was examined with a modification of the method described by Palmero et al. (2012). Cloves of garlic cultivar 'Bosut' were surface disinfested in $0.5 \%$ sodium hypochlorite $(\mathrm{NaOCl})$ (Sigma-Aldrich) for $1 \mathrm{~min}$, washed with sterile water four times, and then injured to a depth of $4 \mathrm{~mm}$ using a 1-mm diameter probe. Each of the 7-day-old fungal isolates on PDA was inoculated into six wounded cloves. Infected wounds were then inoculated with drops of bacterial suspension of selected Bacillus isolates $\left(10^{8} \mathrm{cfu} \mathrm{ml}^{-1}\right)$. For each fungal isolate, another set of six infected cloves was used as a positive control without bacterial treatment. Clove sets inoculated only with sterile PDA or with bacterial suspensions were used as negative control. Treated cloves were incubated in folded, plastic boxes in a growth chamber at $25^{\circ} \mathrm{C}$ for 3 weeks, and then monitored for the development of rot symptoms. Disease symptoms were graded into five classes: $1=<10 \%$ rotted cloves, $2=11-20 \%$ rotted cloves, $3=21-50 \%$ rotted cloves, $4=51-80 \%$ rotted cloves, $5=81-100 \%$ rotted cloves and severe symptoms on cloves. Assay was repeated once, with three replications for each fungal and bacterial isolate. A disease severity index was calculated as the mean of six cloves and three test replicates.

Statistical analysis. Data were processed using a one-way analysis of variance (ANOVA). Means were compared using Tukey's multiple comparisons of means test for $95 \%$ and $99 \%$ confidence levels. All analyses were performed in STATISTICA 10 (StatSoft Inc., USA).

\section{Results and discussion}

Our results confirmed the presence of Bacillus spp. in soil samples collected at different locations in Serbia. Species of Bacillus are characterized as Grampositive, motile, aerobic or facultatively anaerobic and usually catalase positive. Cells are straight rods, often arranged in pairs or chains. Colonies are round, with entire or wavy margins, typically cream and dry or pasty looking.
In search of efficient biocontrol agents, 65 indigenous Bacillus spp. isolates were primarily characterized according to their ability to produce hydrolytic enzymes. Lytic enzymes such as chitinases, glucanases, cellulases, lipases, and proteases, degrade fungal and bacterial cell wall and prevent plant infection caused by pathogens. According to Raza et al. (2008), isolation and characterization of strains which can produce lytic enzymes should be done to achieve maximal survival of bacteria under detrimental environmental conditions and intrusion of pathogens. In this study, hydrolytic activity, i.e. production of one or more enzymes, was found in 32 isolates, while among them, activity of lipase, phospholipase, cellulase, and pectinase was determined in $43.75,12.5,81.2$ and $37.5 \%$ of Bacillus spp. isolates, respectively (Table 2). It has been found that isolates of Bacillus spp. which have the capability to produce lytic enzymes are more effective in the suppression of plant pathogens (Abdallah et al., 2017). Considering the above facts, isolates positive for hydrolytic enzyme production were identified and further screened for their biocontrol potential by examination of antifungal activity and lipopeptide production.

The Bacillus species differentiation is difficult because of their large number (over 200 described species and subspecies) and often incomplete descriptions of the newly-reported species. In this study, identification of Bacillus isolates based on 16S rDNA homology was performed using PCR with the primers 27F and 1492R (Weisburg et al., 1991). The presence of amplicon of $\sim 1460$ bp in size was confirmed in all investigated samples.

Comparison of the sequences with the Bacillus ID-database identified seven isolates as Bacillus megaterium (B8, B9, B12, B14, B15, B16 and B17), six as B. cereus (B6, B24, B27, B29, B30 and $\mathrm{B} 31)$, five as $B$. pumilus (B3, B11, B21, B22 and B23), four as Lysinibacillus fusiformis (B1, B4, B10 and $\mathrm{B} 25)$ and $B$. subtilis (B5, B7, B13 and B32), three as B. thuringiensis (B18, B20 and B28), and one isolate as B. safensis (B2), Lysinibacillus sphaericus (B19) and 
Table 2. Hydrolytic enzyme production of indigenous Bacillus spp. isolates

\begin{tabular}{|c|c|c|c|c|c|c|}
\hline Isolate & Isolation source & Lipase & Phospholipase & Cellulase & Pectinase & $\begin{array}{c}\text { Total } \\
\text { enzymes }\end{array}$ \\
\hline B1 & Agricultural soil & + & - & + & - & 2 \\
\hline B2 & Non-agricultural soil & + & - & + & - & 2 \\
\hline B3 & Rhizosphere (wheat) & + & - & + & + & 3 \\
\hline B4 & Non-agricultural soil & - & - & + & - & 1 \\
\hline B5 & Rhizosphere (sunflower) & + & + & + & + & 4 \\
\hline B6 & Non-agricultural soil & + & - & - & + & 2 \\
\hline B7 & Rhizosphere (maize) & + & - & + & + & 3 \\
\hline B8 & Rhizosphere (pepper) & - & - & + & + & 2 \\
\hline B9 & Rhizosphere (alfalfa) & - & - & + & - & 1 \\
\hline B10 & Non-agricultural soil & - & - & + & + & 2 \\
\hline B11 & Non-agricultural soil & + & + & + & - & 3 \\
\hline B12 & Agricultural soil & - & - & - & + & 1 \\
\hline B13 & Rhizosphere (maize) & + & + & - & + & 3 \\
\hline B14 & Rhizosphere (sunflower) & - & - & + & - & 1 \\
\hline B15 & Non-agricultural soil & + & - & + & - & 2 \\
\hline B16 & Rhizosphere (maize) & - & - & + & - & 1 \\
\hline B17 & Rhizosphere (wheat) & - & - & + & - & 1 \\
\hline B18 & Agricultural soil & - & - & + & - & 1 \\
\hline B19 & Non-agricultural soil & - & - & + & - & 1 \\
\hline $\mathrm{B} 20$ & Non-agricultural soil & - & - & + & - & 1 \\
\hline B21 & Agricultural soil & - & - & + & + & 2 \\
\hline B22 & Rhizosphere (maize) & + & - & + & + & 3 \\
\hline B23 & Rhizosphere (wheat) & + & - & + & + & 3 \\
\hline B24 & Rhizosphere (maize) & - & - & + & - & 1 \\
\hline $\mathrm{B} 25$ & Non-agricultural soil & - & - & + & - & 1 \\
\hline B26 & Agricultural soil & + & - & - & - & 1 \\
\hline $\mathrm{B} 27$ & Non-agricultural soil & - & + & - & - & 1 \\
\hline B28 & Agricultural soil & - & - & + & - & 1 \\
\hline B29 & Non-agricultural soil & + & - & - & - & 1 \\
\hline B30 & Agricultural soil & - & - & + & - & 1 \\
\hline B31 & Non-agricultural soil & - & - & + & - & 1 \\
\hline \multirow[t]{2}{*}{$\mathrm{B} 32$} & Non-agricultural soil & + & - & + & + & 3 \\
\hline & Total production ( $\%$ isolates) & 43.75 & 12.5 & 81.2 & 37.5 & \\
\hline
\end{tabular}

B. mycoides (B26). The gene sequences had the values $99 \%$ to $100 \%$ similar to those deposited in the GenBank: Bacillus megaterium BOFC15 (KU851253), B. cereus ISE27 (KX035061), B. pumilus LX11 (KP192031), Lysinibacillus fusiformis VC-1 (HQ610620), B. subtilis CR26 (KR780430), B. thuringiensis S40 (KY120371), B. safensis ZN9 (KJ542766), Lysinibacillus sphaericus ARD1 (KX023224) and B. mycoides FJAT-44618 (KX767102). Sequences of the isolated Bacillus species were deposited in the NCBI GenBank database under a unique accession number (B1-B11: KU953922KU953931, B12-B26: KX444638-KX444652 and B27-B32: KX766368-KX766373). Similarly, MandicMulec and Prosser (2011) found that up to $95 \%$ of the sequences of Gram-positive bacteria from agricultural soils originate from Bacillus species, while B. cereus and $B$. megaterium were the most commonly found isolates. Also, a high genetic diversity of Bacillus species implies that investigation and identification of new strains may increase the number of potential biocontrol agents and improve understanding of mechanisms associated with antagonistic interactions (Mardanova et al., 2017).

According to the morphological characterization of 20 fungal isolates obtained from garlic cloves,
6 representative isolates of Fusarium spp. were confirmed as causal agents of rot disease. Although plants did not show symptoms of infection in the field, bulb rot later occurred in storage. Our research results confirm that the postharvest storage conditions greatly influence the intensity of garlic clove rot caused by Fusarium (Palmero et al., 2013). Fusarium spp. caused similar symptoms on stored garlic and it was difficult to distinguish them based on the symptoms and morphological characteristics. Molecular identification may assist in further epidemiological studies and development of efficient disease control for this pathosystem. In this study, identification of Fusarium isolates based on EF-1 $\alpha$ gene was performed using PCR with the primers EF1 and EF2 (Geiser et al., 2004) and the presence of amplicon $\sim 700$ bp in size was detected in all examined isolates.

In comparison with the sequences from the Fusarium ID-database, isolates were identified as Fusarium tricinctum (BL12), F. oxysporum f. sp. cepae (BL13), F. proliferatum (BL16 and BL18), F. acuminatum (BL20) and $F$. verticillioides (BL21) (Table 3). BLASTn queries of gene sequences showed $99 \%$ to $100 \%$ identity to $F$. tricinctum, $F$. oxysporum f. sp. cepae, $F$. proliferatum, $F$. acuminatum and $F$. verticilioides, to

Table 3. Isolates of Fusarium spp. from garlic

\begin{tabular}{clll}
\hline Isolate & \multicolumn{1}{c}{ Isolation source } & \multicolumn{1}{c}{ Species } & NCBI account No. \\
\hline BL12 & Garlic genotype JBL12 & Fusarium tricinctum & KX611146 \\
BL13 & Garlic genotype JBL13 & Fusarium oxysporum f. sp. cepae & KX752415 \\
BL16 & Garlic genotype JBL531 & Fusarium proliferatum & KX752417 \\
BL18 & Garlic genotype JBL535 & Fusarium proliferatum & KX752419 \\
BL20 & Garlic genotype JBL539 & Fusarium acuminatum & KX752420 \\
BL21 & Garlic genotype R1 & Fusarium verticillioides & \\
\hline
\end{tabular}


accessions EU744838, KP964881, KP964907, KJ194170 and KU372138, respectively. Sequences of the isolated Fusarium species were deposited in the NCBI GenBank database (Table 3).

The antifungal activity of Bacillus spp. isolates against six isolates of Fusarium spp. was examined using a dual plate assay. The results showed that 10 out of the 32 isolates of Bacillus spp. from soil were positive for antifungal activity (Table 4). Bacillus spp. exhibited the highest antifungal activity against fungal isolate F. tricinctum BL12, while they had the least antagonistic effect on $F$. proliferatum BL16 and $F$. acuminatum BL20. On average, percent of growth inhibition (PGI) obtained by confrontation of the active Bacillus spp. isolates with tested phytopathogenic fungi ranged from
$15.97 \%$ to $58.14 \%$. The highest antifungal activity toward $F$. oxysporum f. sp. cepae BL13, F. proliferatum BL18, $F$. acuminatum BL20 and $F$. verticillioides BL21 was exhibited by isolate $B$. subtilis B5 (from $41.96 \%$ to $66.51 \%$ reduction in fungal growth), while isolate B. subtilis $\mathrm{B} 32$ showed the highest antagonistic effect against $F$. tricinctum BL12 and $F$. proliferatum BL16 (from $44.31 \%$ to $71.37 \%$ reduction in fungal growth). B. subtilis isolates B7 and B13 also demonstrated good antifungal potential (PGI up to $69.01 \%$ and $63.14 \%$ ), while the effect of B. safensis (B2) and B. pumilus (B3, $\mathrm{B} 11, \mathrm{~B} 21, \mathrm{~B} 22$ and B23) isolates varied depending on the tested fungi. Also, effective Bacillus spp. isolates were better producers of lytic enzymes (Table 2 ).

Table 4. Mean values and analysis of variance (significance) for antifungal activity of effective Bacillus spp. isolates against Fusarium spp.

\begin{tabular}{lcccccc}
\hline \multirow{2}{*}{ Isolate } & $\begin{array}{c}\text { F. tricinctum } \\
\text { BL12 }\end{array}$ & $\begin{array}{c}\text { F. oxysporum f. } \\
\text { sp. cepae BL13 }\end{array}$ & $\begin{array}{c}\text { F. proliferatum } \\
\text { BL16 }\end{array}$ & $\begin{array}{c}\text { F. proliferatum } \\
\text { BL18 }\end{array}$ & $\begin{array}{c}\text { F. acuminatum } \\
\text { BL20 }\end{array}$ & $\begin{array}{c}\text { F. verticillioides } \\
\text { BL21 }\end{array}$ \\
\cline { 2 - 7 } & & & Percent of growth inhibition \% & \\
\hline B. safensis B2 & $49.4 \mathrm{de}$ & $30.4 \mathrm{~d}$ & $19.2 \mathrm{de}$ & $42.7 \mathrm{~d}$ & $13.2 \mathrm{~d}$ & $28.0 \mathrm{~d}$ \\
B. pumilus B3 & $54.3 \mathrm{~cd}$ & $12.7 \mathrm{e}$ & $19.8 \mathrm{de}$ & $42.4 \mathrm{~d}$ & $12.7 \mathrm{~d}$ & $30.0 \mathrm{~d}$ \\
B. subtilis B5 & $65.5 \mathrm{ab}$ & $59.6 \mathrm{a}$ & $43.1 \mathrm{a}$ & $62.6 \mathrm{a}$ & $42.0 \mathrm{a}$ & $66.5 \mathrm{a}$ \\
B. subtilis B7 & $69.0 \mathrm{ab}$ & $54.9 \mathrm{ab}$ & $34.3 \mathrm{~b}$ & $53.3 \mathrm{bc}$ & $35.5 \mathrm{~b}$ & $52.2 \mathrm{~b}$ \\
B. pumilus B11 & $44.1 \mathrm{e}$ & $36.7 \mathrm{~cd}$ & $28.8 \mathrm{bc}$ & $40.4 \mathrm{~d}$ & - & - \\
B. subtilis B13 & $63.1 \mathrm{abc}$ & $43.3 \mathrm{c}$ & $27.3 \mathrm{c}$ & $49.0 \mathrm{c}$ & $16.2 \mathrm{~d}$ & $42.0 \mathrm{c}$ \\
B. pumilus B21 & $55.7 \mathrm{~cd}$ & $32.0 \mathrm{~d}$ & $16.4 \mathrm{e}$ & - & - & $15.2 \mathrm{e}$ \\
B. pumilus B22 & $47.7 \mathrm{de}$ & - & $4.5 \mathrm{f}$ & - & - & - \\
B. pumilus B23 & $61.2 \mathrm{bc}$ & $29.6 \mathrm{~d}$ & $25.7 \mathrm{~cd}$ & $39.8 \mathrm{~d}$ & $14.9 \mathrm{~d}$ & $28.4 \mathrm{~d}$ \\
B. subtilis B32 & $71.4 \mathrm{a}$ & $50.6 \mathrm{~b}$ & $44.3 \mathrm{a}$ & $57.5 \mathrm{~b}$ & $25.3 \mathrm{c}$ & $63.7 \mathrm{a}$ \\
\hline Average & 58.1 & 35.0 & 26.3 & 38.8 & 16.0 & 32.6 \\
Isolate & $* *$ & $* *$ & $* *$ & $* *$ & $* *$ & $* *$ \\
\hline
\end{tabular}

Note. Means with different lowercase letters in the same column within the same fungal isolate and effective Bacillus spp. isolates are significantly different $(p<0.05$, Tukey test); $* *$ - significance at 0.01 probability level.

In our previous study, we observed very strong antifungal activity of $B$. subtilis $\mathrm{B} 5$ and $\mathrm{B} 7$ against F. proliferatum BL5 (KX092461) and F. oxysporum f. sp. cepae BL7 (KX092466), while the antagonistic effect of Bacillus isolates toward $F$. verticillioides BL7 (KX092464) was not detected (Bjelić et al., 2017).

Antifungal compounds involve mainly peptides that are generated ribosomally or non-ribosomally. The most frequent antibiotic and surface-active compounds in Bacillus spp. are cyclic lipopeptides of surfactin, iturin and fengycin families, synthesized non-ribosomally by large multienzyme complexes (Cawoy et al., 2015). The surfactin family (surfactin, lichenysins and pumilacidins) comprises heptapeptides containing a $\beta$-hydroxy fatty acid with a number of carbon atoms between 13 and 16 . Lipopeptides of the iturin family (iturin, mycosubtilin and bacillomycin) are composed of heptapeptides interlinked with a $\beta$-amino fatty acid chain, consisting of 14-17 carbons. Members of the fengycin family, represented by plipastatin, are cyclic lipodecapeptides with a $\beta$-hydroxy fatty acid having side chain length of 16-19 carbon atoms. In this study, PCR amplifications using specific primers were performed to search the genes involved in the surfactin ( $s f p)$, iturin (itu), bacillomycin $\mathrm{D}($ bam C) or fengycin (fenD) antibiotics biosynthesis in 32 Bacillus spp. isolates. Consequently, only the $s f p$ gene (675 bp) was amplified from B. subtilis B5, B7, B13 and $\mathrm{B} 32$, suggesting that these four isolates could produce surfactin (Fig.).

Previous studies showed that most strains of Bacillus produce lipopeptides from one family, while a few were identified as co-producers of lipopeptides belonging to different families (Ongena, Jacques, 2008). Moreover, it was determined that the antifungal activity of Bacillus spp. depends on the quantity and diversity in the production of lipopeptides (Nagorska et al., 2007). Four isolates of $B$. subtilis which exhibited the highest antagonistic effect during in vitro testing of antifungal
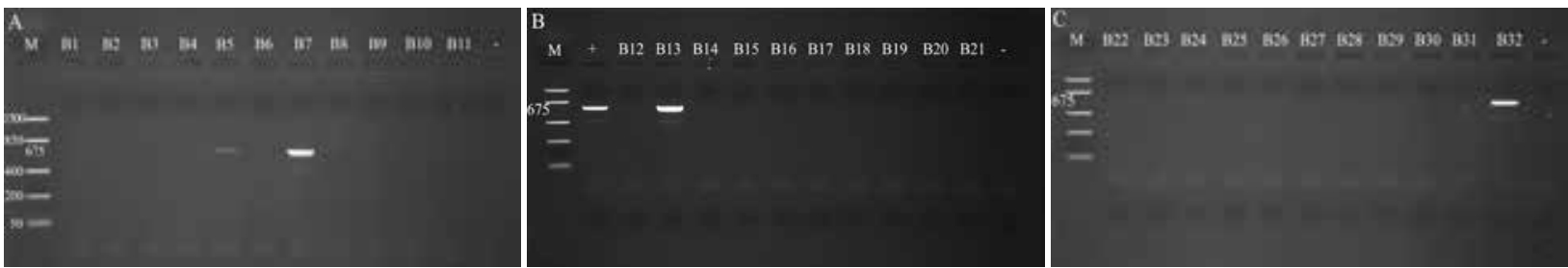

M - PCR marker (Step Ladder, 50-1500 bp), - - negative control

Figure. Polymerase chain reaction (PCR) screening for antibiotic biosynthetic genes in Bacillus spp. isolates detection of sfp gene in B1-B11 (A), B12-B21 (B) and B22-B32 (C) isolates 
activity (Table 4), as well as the ability to produce lipopeptide surfactin (Fig.), were selected for in situ antifungal activity assay on garlic cloves infected with isolates of Fusarium spp.

By assessing the symptoms of rotted cloves in control treatments, the highest disease severity indexes were determined for Fusarium acuminatum BL20, followed by $F$. proliferatum BL16 and $F$. oxysporum $\mathrm{f}$. sp. cepae BL13, while F. tricinctum BL12 and $F$. proliferatum BL18 had the lowest pathogenicity (Table 5). On average, all four Bacillus isolates reduced the occurence of rot symptoms (from $28 \%$ to $40 \%$ ). Bacterial isolates had the highest antifungal activity toward $F$. oxysporum f. sp. cepae BL13 and $F$. proliferatum BL16, followed by their equally good antagonistic effect on other fungal isolates.
Disease severity index values from garlic cloves inoculated with both fungal and bacterial isolates were significantly lower than in controls inoculated with Fusarium spp. isolates. Isolate B5 significantly reduced (up to $58 \%$ ) the occurrence of rot symptoms on cloves infected with fungal isolates BL13, BL16, BL18, BL20 and BL21. A significant suppression of infection compared to the control treated with isolates BL13, BL18 and BL20 was also achieved by isolate B7 (up to 52\%), while isolate B32 led to significant decrease of garlic rot caused by fungal isolates BL12, BL13 and BL21 (up to $45 \%$ ). Isolate B13 also reduced (up to $27 \%$ ) the symptom development on infected cloves, although without significant differences compared to control treatments.

Table 5. Mean values and analysis of variance (significance) for antifungal activity of selected Bacillus isolates on garlic cloves infected with Fusarium spp.

\begin{tabular}{|c|c|c|c|c|c|c|c|}
\hline Isolate & $\begin{array}{l}\text { F. tricinctum } \\
\text { BL12 }\end{array}$ & $\begin{array}{l}\text { F. oxysporum f. } \\
\text { sp. cepae BL } 13\end{array}$ & $\begin{array}{c}F \text { proliferatum } \\
\text { BL16 }\end{array}$ & $\begin{array}{c}F . \text { proliferatum } \\
\text { BL18 }\end{array}$ & $\begin{array}{c}\text { F. acuminatum } \\
\text { BL20 }\end{array}$ & $\begin{array}{l}\text { F. verticillioides } \\
\text { BL21 }\end{array}$ & Average \\
\hline \multicolumn{8}{|c|}{ Disease severity index } \\
\hline Pathogen & $3.7 \mathrm{a}$ & $4.2 \mathrm{a}$ & $4.3 \mathrm{a}$ & $3.8 \mathrm{a}$ & $4.8 \mathrm{a}$ & $4.0 \mathrm{a}$ & 4.1 \\
\hline B.subtilis B5 & $2.7 \mathrm{ab}$ & $2.5 \mathrm{~b}$ & $1.8 \mathrm{~b}$ & $2.2 \mathrm{~b}$ & $2.7 \mathrm{~b}$ & $2.3 \mathrm{~b}$ & 2.4 \\
\hline B. subtilis B7 & $2.7 \mathrm{ab}$ & $2.0 \mathrm{~b}$ & $2.7 \mathrm{ab}$ & $2.7 \mathrm{~b}$ & $3.2 \mathrm{~b}$ & $3.2 \mathrm{ab}$ & 2.7 \\
\hline B. subtilis B13 & $3.2 \mathrm{ab}$ & $3.3 \mathrm{ab}$ & $3.2 \mathrm{ab}$ & $3.0 \mathrm{ab}$ & $4.0 \mathrm{ab}$ & $3.5 \mathrm{ab}$ & 3.4 \\
\hline B. subtilis B32 & $2.0 \mathrm{~b}$ & $2.5 \mathrm{~b}$ & $2.7 \mathrm{ab}$ & $2.8 \mathrm{ab}$ & $3.7 \mathrm{ab}$ & $2.5 \mathrm{~b}$ & 2.7 \\
\hline Average & 2.6 & 2.6 & 2.6 & 2.7 & 3.4 & 2.9 & \\
\hline Isolate & $* *$ & $* *$ & $* *$ & $* *$ & $* *$ & $*$ & \\
\hline
\end{tabular}

Note. Means with different lowercase letters in the same column within the same fungal isolate and selected Bacillus spp. isolates are significantly different $(p<0.05$, Tukey test $) ;{ }^{*}$ - significance at 0.01 probability level, ${ }^{*}$ - significance at 0.05 probability level.

Unlike the tested fungal species which showed different sensitivity in antifungal activity assays, the antagonistic effect of the particular Bacillus isolates via in vitro and in situ testing largely coincided. Interestingly, newly-isolated Bacillus spp. exhibited the least in vitro antagonistic effect on fungal isolates which had the highest in situ pathogenicity. Similarly, Dimkić et al. (2015) found that Fusarium spp. are among the most resistant phytopathogenic fungi to the antagonistic effect of Bacillus spp., while within genus there was a higher resistance of $F$. verticillioides and $F$. oxysporum in relation to $F$. tricinctum.

The present study showed that the highest and the most extensive antagonistic effect toward all the tested fungi was achieved by isolates of $B$. subtilis, probably due to the production of lipopeptide surfactin and hydrolytic enzymes. In fact, Stein (2005) showed that B. subtilis had strong inhibitory effect against more pathogens as a result of the production of antibiotics. Additionally, Mardanova et al. (2017) established that B. subtilis was able to suppress Fusarium infection through the production of hydrolytic enzymes and cyclic lipopeptides. Numerous studies revealed that antagonistic strains of $B$. subtilis which inhibit the fungal growth under in vitro conditions also reduce the production of mycotoxins, as well as the occurrence and frequency of Fusarium caused diseases of various plants in greenhouse and field conditions (Cavaglieri et al., 2005; Baysal et al., 2008; Zalila-Kolsi et al., 2016). However, these are the first data about possible use of B. subtilis in biocontrol of Fusarium spp. isolated from infected garlic cloves, so further research will be of great importance. In addition to their effect on Fusarium, Bacillus isolates show antagonistic activities against numerous fungal and bacterial pathogens $(\mathrm{Wu}$ et al., 2015). Besides their role in biocontrol, Bacillusbased preparations should also have the ability to colonize rhizosphere and promote plant growth (Borriss, 2011). The isolation and characterization of these bacteria is very important from the viewpoint of biocontrol research and could increase the number of strains identified as biocontrol agents of various diseases covering a wider range of plant species.

\section{Conclusions}

1. Isolates of Bacillus subtilis, B. safensis and B.pumilus as superior enzyme producers showed antifungal activity against Fusarium tricinctum, F. oxysporum f. sp.cepae, F. proliferatum, F. verticillioides and $F$. acuminatum.

2. The highest antagonistic effect toward this important pathosystem was observed for B. subtilis isolates, and very strong antifungal activity of these isolates was confirmed by significant suppression of common garlic (Allium sativum L.) cloves infection.

3. Polymerase chain reaction (PCR) analysis of antimicrobial compounds showed that antifungal activity of $B$. subtilis isolates was merit of lipopeptide surfactin production.

4. Based on our results, B. subtilis isolates could be used as biocontrol agents of garlic clove rot caused by Fusarium spp., and to our knowledge, this is the first experimental confirmation on using Bacillus spp. in biocontrol of the pathogens involved in this disease.

5. This study revealed that the indigenous Bacillus isolates from the soil have strong biocontrol potential and could be used for suppression of plant diseases and improvement of plant productivity.

6. Further research of effective Bacillus isolates through greenhouse and field trials will be necessary in order to establish their efficiency as biopesticides in different environmental conditions. 


\section{Acknowledgments}

This research is supported by the Ministry of Education, Science and Technological Development of the Republic of Serbia (projects No. TR-31030 and TR-31072).

Received 19122017

Accepted 27062018

\section{References}

1. Abdallah R. A. B., Stedel C., Garagounis C., Nefzi A., Jabnoun-Khiareddine H., Papadopoulou K. K., DaamiRemadi M. 2017. Involvement of lipopeptide antibiotics and chitinase genes and induction of host defense in suppression of Fusarium wilt by endophytic Bacillus spp. in tomato. Crop Protection, 99: 45-58. https://doi.org/10.1016/j.cropro.2017.05.008

2. Ansari M., Ahmad N., Hasan F. 2012. Potential of biopesticides in sustainable agriculture. Malik A., Grohmann E. (eds). Environmental protection strategies for sustainable development. Springer, p. 529-595.

3. Baysal Ö., Çalıșkan M., Yeșilova Ö. 2008. An inhibitory effect of a new Bacillus subtilis strain (EU07) against Fusarium oxysporum f. $\mathrm{sp}$. radicis-lycopersici. Physiological and Molecular Plant Pathology, 73 (1-3): 25-32. https://doi.org/10.1016/j.pmpp.2008.11.002

4. Bjelić D., Ignjatov M., Marinković J., Spremo N., Karaman M., Nikolić Z., Ivanović Ž. 2017. Antifungal activity of indigenous Bacillus spp. isolated from soil. Matica Srpska Journal for Natural Sciences, 133: 261-269. https://doi.org/10.2298/ZMSPN1733261B

5. Borriss R. 2011. Use of plant-associated Bacillus strains as biofertilizers and biocontrol agents in agriculture. Maheshwari D. K. (ed.). Bacteria in agrobiology: plant growth responses. Springer, p. 41-76.

6. Cappuccino J. G., Welsh C. T. 2016. Microbiology: a laboratory manual $\left(11^{\text {th }}\right.$ ed.). Pearson, $560 \mathrm{p}$.

7. Cavaglieri L., Orlando J., Etcheverry M. 2005. In vitro influence of bacterial mixtures on Fusarium verticillioides growth and fumonisin B1 production: effect of seeds treatment on maize root colonization. Letters in Applied Microbiology, 41: 390-396. https://doi.org/10.1111/j.1472-765X.2005.01785.x

8. Cawoy H., Debois D., Franzil L., De Pauw E., Thonart P., Ongena M. 2015. Lipopeptides as main ingredients for inhibition of fungal phytopathogens by Bacillus subtilis/ amyloliquefaciens. Microbial Biotechnology, 8 (2): 281-295. https://doi.org/10.1111/1751-7915.12238

9. Dimkić I., Živkovic S., Berić T., Ivanović Ž., Gavrilović V., Stanković S., Fira Dj. 2013. Characterization and evaluation of two Bacillus strains, SS-12.6 and SS-13.1, as potential agents for the control of phytopathogenic bacteria and fungi. Biological Control, 65: 312-321. https://doi.org/10.1016/j.biocontrol.2013.03.012

10. Dimkić I., Berić T., Stević T., Pavlović S., Šavikin K., Fira Đ., Stanković S. 2015. Additive and synergistic effects of Bacillus spp. isolates and essential oils on the control of phytopathogenic and saprophytic fungi from medicinal plants and marigold seeds. Biological Control, 87: 6-13. https://doi.org/10.1016/j.biocontrol.2015.04.011

11. Djuric S., Pavic A., Jarak M., Pavlovic S., Starovic M., Pivic R., Josic D. 2011. Selection of indigenous fluorescent pseudomonad isolates from maize rhizospheric soil in Vojvodina as possible PGPR. Romanian Biotechnological Letters, 16: 6580-6590.

12. Dugan F. M., Hellier B. C., Lupien S. L. 2007. Pathogenic fungi in garlic seed cloves from the United States and China, and efficacy of fungicides against pathogens in garlic germplasm in Washington State. Journal of Phytopathology, 155: 437-445.

https://doi.org/10.1111/j.1439-0434.2007.01255.x
13. Geiser D. M., del Mar Jiménez-Gasco M., Kang S., Makalowska I., Veeraraghavan N., Ward T. J., Zhang N., Kuldau G. A., O'Donnell K. O. 2004. Fusarium-ID v. 1.0: a DNA sequence database for identifying Fusarium. European Journal of Plant Pathology, 110: 473-479. https://doi.org/10.1023/B:EJPP.0000032386.75915.a0

14. Ignjatov M., Bjelić D., Nikolić Z., Milošević D., Gvozdanović-Varga J., Marinković J., Ivanović Ž. 2017 (a). First report of Fusarium acuminatum causing garlic bulb rot in Serbia. Plant Disease, 101 (6): 1047.

15. Ignjatov M., Milošević D., Nikolić Z., Gvozdanović-Varga J., Tatić M., Popović T., Ivanović Ž. 2017 (b). First report of Fusarium tricinctum causing garlic bulb rot in Serbia. Plant Disease, 101 (2): 382.

16. Islam M. R., Jeong Y. T., Lee Y. S., Song C. H. 2012. Isolation and identification of antifungal compounds from Bacillus subtilis C9 inhibiting the growth of plant pathogenic fungi. Mycobiology, 40 (1): 59-66 https://doi.org/10.5941/MYCO.2012.40.1.059

17. Koleva K. 2004. Variety of species and spread of fungi of genus Fusarium related to rotting of garlic. Bulgarian Journal of Agricultural Science, 10: 177-180.

18. Leslie J. F., Summerell B. A. 2006. The fusarium laboratory manual. Blackwell Publishing, $388 \mathrm{p}$ https://doi.org/10.1002/9780470278376

19. Lević J., Stanković S., Krnjaja V., Bočarov-Stančić A. 2009. Fusarium species: the occurrence and the importance in agriculture of Serbia. Matica Srpska Proceedings for Natural Sciences, 116: 33-48. https://doi.org/10.2298/ZMSPN0916033L

20. Lugtenberg B., Malfanova N., Kamilova F., Berg G. 2013. Microbial control of plant diseases. Bruijn de F. J. (ed.). Molecular microbial ecology of the rhizosphere. WileyBlackwell Publishing, p. 67-91.

21. Mandic-Mulec I., Prosser J. I. 2011. Diversity of endospore-forming bacteria in soil: characterization and driving mechanisms. Logan N., Vos P. (eds). Endosporeforming soil bacteria. Springer, p. 31-59.

22. Mardanova A. M., Hadieva G. F., Lutfullin M. T., Khilyas I. V., Minnullina L. F., Gilyazeva A. G., Bogomolnaya L. M., Sharipova M. R. 2017. Bacillus subtilis strains with antifungal activity against the phytopathogenic fungi. Agricultural Sciences, 8: 1-20. https://doi.org/10.4236/as.2017.81001

23. Martins N., Petropoulos S., Ferreira I. 2016. Chemical composition and bioactive compounds of garlic (Allium sativum $\mathrm{L}$.) as affected by pre- and post-harvest conditions: a review. Food Chemistry, 211: 41-50. https://doi.org/10.1016/j.foodchem.2016.05.029

24. Mnif I., Ghribi D. 2015. Potential of bacterial derived biopesticides in pest management. Crop Protection, 77: 52-64. https://doi.org/10.1016/j.cropro.2015.07.017

25. Nagorska K., Bikowski M., Obuchowki M. 2007. Multicellular behaviour and production of a wide variety of toxic substance support usage of Bacillus subtilis as powerful biocontrol agent. Acta Biochimica Polonica, 254: 495-508.

26. Ongena M., Jacques P. 2008. Bacillus lipopeptides: versatile weapons for plant disease biocontrol. Trends in Microbiology, 16 (3): 115-125. https://doi.org/10.1016/j.tim.2007.12.009

27. OSU. 2008. Fusarium rot of garlic bulbs. Oregon State University, USA. http://www.science.oregonstate.edu/bpp/ Plant Clinic/Garlic/Fusarium.pdf

28. Palmero D., De Cara M., Nosir W., Galvez L., Cruz A., Woodward S., Gonzalez-Jaen M. T., Tello J. C. 2012. Fusarium proliferatum isolated from garlic in Spain: identification, toxigenic potential and pathogenicity on related Allium species. Phytopathologia Mediterranea, 51 (1): 207-218.

29. Palmero D., Gálvez L., García M., Gil J., Benito S. 2013. The effects of storage duration, temperature and cultivar on the severity of garlic clove rot caused by Fusarium proliferatum. Postharvest Biology and Technology, 78: 34-39. https://doi.org/10.1016/j.postharvbio.2012.12.003 
30. Rahman M. S. 2007. Allicin and other functional active components in garlic: health benefits and bioavailability. International Journal of Food Properties, 10: 245-268. https://doi.org/10.1080/10942910601113327

31. Raza W., Yang W., Shen Q-R. 2008. Paenibacillus polymyxa: antibiotics, hydrolytic enzymes and hazard assessment. Journal of Plant Pathology, 90 (3): 419-430.

32. Schwartz H. F., Mohan S. K. 2008. Compendium of onion and garlic diseases and pests. APS Press, $127 \mathrm{p}$.

33. Stanković S., Lević J., Petrović T., Logrieco A., Moretti A. 2007. Pathogenicity and mycotoxin production by Fusarium proliferatum isolated from onion and garlic in Serbia. European Journal of Plant Pathology, 118: 165-172. https://doi.org/10.1007/s10658-007-9126-8

34. Stein T. 2005. Bacillus subtilis antibiotics: structures, syntheses and specific functions. Molecular Microbiology, 56: $845-857$.

https://doi.org/10.1111/j.1365-2958.2005.04587.x
35. Weisburg W. G., Barns S. M., Pelletier D. A., Lane D. J. 1991. 16S ribosomal DNA amplification for phylogenetic study. Journal of Bacteriology, 173 (2): 697-703. https://doi.org/10.1128/jb.173.2.697-703.1991

36. Wu L., Wu H-J., Qiao J., Gao X., Borriss R. 2015. Novel routes for improving biocontrol activity of Bacillus based bioinoculants. Frontiers in Microbiology, 6: 1395. https://doi.org/10.3389/fmicb.2015.01395

37. Zalila-Kolsi I., Mahmoud A. B., Ali H., Sellami S., Nasfi Z., Tounsi S., Jamoussi K. 2016. Antagonist effects of Bacillus spp. strains against Fusarium graminearum for protection of durum wheat (Triticum turgidum L. subsp. durum). Microbiological Research, 192: 148-158. https://doi.org/10.1016/j.micres.2016.06.012

38. Zhao Z., Wang Q., Wang K., Brian K., Liu C., Gu Y. 2010. Study of the antifungal activity of Bacillus vallismortis ZZ185 in vitro and identification of its antifungal components. Bioresource Technology, 101: 292-297. https://doi.org/10.1016/j.biortech.2009.07.071

ISSN 1392-3196 / e-ISSN 2335-8947

Zemdirbyste-Agriculture, vol. 105, No. 4 (2018), p. 369-376

DOI 10.13080/z-a.2018.105.047

\title{
Bacillus izoliatai česnakų skiltelių fuzarinio puvinio biokontrolei
}

\author{
D. Bjelić ${ }^{1}$, M. Ignjatov ${ }^{1}$, J. Marinković 1 , D. Milošević ${ }^{1}$, Z. Nikolić ${ }^{1}$, J. Gvozdanović-Varga ${ }^{1}$, \\ M. Karaman ${ }^{2}$ \\ ${ }^{1}$ Serbijos lauko ir daržo augalų institutas \\ ${ }^{2}$ Novi Sado universitetas, Serbija
}

\section{Santrauka}

Skiltelių fuzarinis puvinys yra labai žalinga valgomojo česnako (Allium sativum L.) liga, pasitaikanti daugelyje pasaulio regionų, tačiau trūksta žinių apie jos sukẻlëjo biologinę kontrolę. Bacillus rūšys mokslui yra ịdomios dèl galimo jų panaudojimo grybinių ligų biologinei kontrolei. Tyrimo tikslas - atrinkti veiksmingas biokontrolès medžiagas iš vietinių Bacillus spp. izoliatų, išskirtų iš dirvožemio. Fusarium spp. buvo išskirti iš užkrèstų česnako skiltelių ir su jais buvo atlikti Bacillus spp. izoliatų, sintetinančių hidrolitinius fermentus, antibakterinio aktyvumo tyrimai. Polimerazès grandininè reakcija (PGR) buvo taikyta molekuliniams bakterinių (16S rDNR genas) ir grybiniams (EF-1 $\alpha$ genas) izoliatams identifikuoti ir antimikrobinių lipopeptidų (surfaktino, iturino, bacilomicino $\mathrm{D}$ ir fengicino) biosintezès genams nustatyti Bacillus spp. rūšyse.

Tyrimo rezultatai patvirtino, kad Fusarium tricinctum, F. oxysporum f. sp. cepae, F. proliferatum, F. acuminatum ir $F$. verticillioides yra česnakų skiltelių fuzarinio puvinio sukèlèjai. Keturi bakteriniai izoliatai, identifikuoti kaip Bacillus subtilis, pademonstravo didžiausią antagonistinį poveikį, antigrybinį aktyvumą tiriant in vitro (grybų augimas sumažintas 71 procentu), ir smarkiai slopino česnakų skiltelių infekciją in situ (grybų augimas sumažintas 58 procentais). Antigrybinių junginių, dalyvaujančių tirtų izoliatų antagonistinėje veikloje, analizè atskleidė jų gebą gaminti antibiotinị lipopeptidą surfaktiną. Patys veiksmingiausi B. subtilis izoliatai gali būti naudojami kaip potencialios biologinès česnakų skiltelių puvinio kontrolès medžiagos.

Reikšminiai žodžiai: Allium sativum, antigrybinis aktyvumas, Bacillus subtilis, lipopeptidai. 